\title{
The Energy Consumption and Gross Domestic Product Nexus in Sri Lanka: Cointegration and Granger Causality Examination
}

\author{
M.N.F. Washima, A.M.M. Mustafa
}

\begin{abstract}
This research purposes to examine the bond between consumption of energy and gross domestic product of Sri Lanka over the period of time 1980 to 2017. To find the order of integration The Augmented Dicky-Fuller (ADF) and Phillips Perron (PP) unit root tests have used. Study examines long-run relationship through the application of Johanson Cointegration techniques. Dependent variable of this study is Gross Domestic Products (GDP) whereas gross capital formation, inflation, oil, gas, and electricity consumption are independent variables. This research has used secondary data and collected data is analyzed by using EViews 10 statistical software. According to the findings, gas consumption has statistically significant negative relationship to the GDP of Sri Lanka whereas labor force, gross capital formation, consumption of electricity and oil are statistically significant positive relationship with GDP. According to the Granger causality findings bi-directional causality exists in oil, gas and electricity consumption in Sri Lanka. This results reveal that consumption of electricity, gas and oil lead to GDP and GDP leads to electricity, gas and oil consumption. Oil and Gas implies the unidirectional causality with electricity. But, oil and gas have no causality in Sri Lanka. Hence, this paper concluded that consumption of energy has a statistically significant relationship with the gross domestic product of Sri Lanka. Thus, this study suggested that Sri Lanka should utilize energy consumptions in the manufacturing and commercial industries to achieve sustainable growth.
\end{abstract}

Keywords : Electricity, gas, gross domestic product, inflation, oil.

\section{INTRODUCTION}

Energy is necessary and desirable since consumption energy has an influential influence on county's sustainable economic growth and quality of life. Energy consumption refers consumption of energy which generate power, fossil fuels and renewable energy. Wind, solar, hydroelectric power and biofuels are included in renewable energy sources (Gillaspy, 2013). Energy creates powerful interlinkages between countries (Overland, 2016). Thus, global countries are related to one another by oil, gas, coal and so on. Thus, energy contributes the globalization of the world. Further, energy is key factor for industrialized and developing countries and it plays a vital role directly and indirectly in the producing goods and services. (Buhari and Osman, 2016).

Revised Version Manuscript Received on 16 September, 2019.

* Correspondence Author

M.N.F. Washima, Department of Economics and Statistics, Faculty of Arts and Culture, South Eastern University of Sri Lanka Oluvil, \# 32360, Sri Lanka. fwaseema@seu.ac.lk

A.M.M. Mustafa, Department of Management, Faculty of Management and Commerce, South Eastern University of Sri Lanka, Oluvil, \# 32360, Sri Lanka. amustafa@seu.ac.1k
Physical availability and quality of energy are important drivers for economic productivity (Michael \& Jemelkova, 2003). Therefore, as energy consumption increases, the economic activity of a country also change. Eventually, consumption of the energy leads to the socio-economic growth and development of a country.

In 2017, world energy consumption raised strongly by 2.2 percent, which was 1.2 percent only in last year. Fuel and natural gas have practiced the highest rise in consumption of energy continued by renewable and oil items. In 2017, the largest market for the energy consumption was china, due to increase in energy consumption by 3.1 percent. According to the International Energy Agency (IEA) report, in 2018, the world energy consumption rose by 2.3 percent. Fossil Fuels and natural gas covered 70 percent and 45 percent in total energy demand growth respectively. Also, CO2 emissions raised by 1.7 percent in 2018 while the share of electricity in the energy consumption of world increased as 20 percent (Jungcurt, 2019). Nowadays, developing countries use 30 percent of world energy containing both commercial and traditional energy. 85 percent of biomass fuel consumption and commercial fuels such as oil, coal, gas, and electricity accounted for 23 percentage were consumed by them. In this countries except to China and India, other countries highly depend on the biomass and oil. The China and India only use the coal. The world's most energy consumers are China, India, Mexico, South Africa and Brazil (Congress, 2019).

In 2013, total energy requirements of Sri Lanka was around 11125-kilo tone. And the supply of the major energy mainly contained of 4814-kilo tone of biomass, 4,582-kilo tone of fossil fuels, and 1442-kilo tone of hydro. As a result, 56 percent of energy is from biomass (4,814-kilo tone) and hydro (1,442-kilo tone) (Ministry of Power and energy, 2015). Despite, main energy supply of Sri Lanka contain biomass, fossil fuels and hydro. Hence, Sri Lanka require to import fuels to reach trade balance. The annual total demand for electricity of Sri Lanka is about 10,500 GWh. Domestic consumers, industries and commercial enterprises utilize electricity as 38\%, 39\% and 20\% respectively. Balance $3 \%$ only consumed by religious organizations and street lighting. In this context, to achieve sustainable growth, Sri Lanka has to maintain a strategic balance between demand and supply of energy

Even though, Sri Lanka faces some challenges in consuming the energy. Namely high electricity cost, transport, demand for imported oil, absence of technology, research and development, large investment on infrastructure development like as power and energy, unmaintainable patterns of energy consumption, energy wastages and increasing demand trends across all sub-sectors. Hence, these

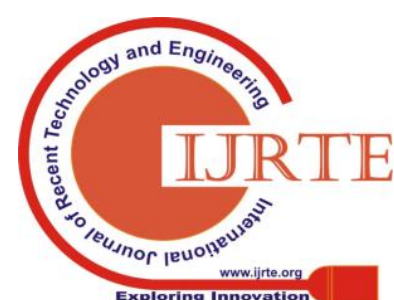


challenges decrease the economic growth of country through decline the productivity of the country.

For that reason, this research work intent to test the relationship between consumption of energy and Gross Domestic product (GDP) of Sri Lanka between the periods of 1980 to 2017. Specifically, this research study targets to empirically identify the causal association between consumption of energy and Gross Domestic Product, to explore long-run association between energy consumption and gross domestic product and to examine effect of all related independent variables on GDP and its future implications.

\section{REVIEW OF LITERATURE}

In theoretical background, classical economic theories implied that land, labor, capital and entrepreneurship are the key inputs of production. But, in recent years day by day, the necessity for energy is growing with the growth of globalization (Buhari and Osman, 2016). Further, Neoclassical growth models suggest that energy is considered as an intermediate input which is produced by the primary factors of production. Furthermore, neoclassical economists often accept that energy and capital are perfectly substitutable inputs in the production of an economy. The connection among economic growth and consumption of energy has been generally examined in the past decades. Faisal, Tursoys and Ercantanb (2017) and Hou (2009) both use the data set for Belgium 1960-2012 and China 1953 - 2006. The examined result of both studies implies contradictory results to each other. And, while Belgium indicates the unidirectional relationship from Gross Domestic Product to energy consumption, china implies the bi-directional causality relationship. The results of Syed and Muhammad (2012) revealed unidirectional interconnection between GDP and energy consumption.

Study investigated in Malaysia from 1980 to 2010, point out that oil and coal consumption does not affect economic growth and vice versa. But, there is a bond among the consumption of electricity and growth (Mohd et al, 2012). Alp (2016) investigated that cointegrating relations for the OECD countries explain a positive relationship between growth and energy consumption. Further, 3 groups of energy hypothesis are observed in OECD countries in 1980 to 2012 and OECD countries are grouped by the neutrality hypothesis, the growth hypothesis, the conservation hypothesis and the feedback hypothesis.

Anthony,(2015) inspected the relationship among consumption of the energy and Gross domestic product on South and Southeast Asian countries by using data from 1990 - 2012. This study revealed that all the variables want a long period of time to touch the long-run equilibrium. Panel Granger causality results show the bidirectional causality effects among energy consumption and growth in South and Southeast Asian countries. According to a research finding, conducted in four developing countries (Pakistan, Bangladesh, India and Sri Lanka) in the period of time 1981-2015, study revealed that there is positive connection between the growth and consumption of energy. But, after introducing the energy-efficient technology increase in trade has a negative correlation with energy consumption (Gulzara, et al, 2018). Imran, et al, (2012) revealed that the electricity consumption is significantly related to growth and other sources of energy. The consumption of oil affects economic growth negatively due to its high level of import. Trade openness has positive impact on economic growth in the period.

\section{DATA ANALYSIS AND METHODOLOGY}

This research is constructed on secondary data containing annual time series observations on Sri Lankan economy for the period of 1980 to 2017. This study has used the Gross Domestic Product (GDP) in million dolor as a dependent variable to examine the association of energy consumption wiht GDP in Sri Lanka. GDP was directly obtained from the annual report of Central Bank of Sri Lanka. The inflation (INF) data was obtained from the International Monetary Fund e-library and International Financial Statistics. Data for Labor Force (LAB), oil consumption (OIL), electricity consumption (ELEC), gas consumption (GAS) and Gross Fixed Capital Formation (GFCF) are obtained from the Annual Report of Central Bank of Sri Lanka and popular statistics database website called Knoema, The Global Economy and World Bank Database and Data of Central Bank of Sri Lanka. The collected data is analyzed using Eview 10 statistical software.

\subsection{Theoretical Framework}

According to the neoclassical models, energy is not included as a element of production. But, nowadays energy become important inputs of production. In this context, the CobbDouglas function is generally used to describe the relationship of input with output. The function is written as:

$$
Y_{t}=A K_{t}^{\propto} L_{t}^{\beta}
$$

Where $Y_{t}$ represents the aggregate output in t, $K_{t}$ is capital, $L_{t}$ is labour, while $\mathrm{A}$ is the proxy of parameter of technology. $\alpha$ and $\beta$ are used to measure the elasticities of output with respect to capital and labour of production. According to Yuan et al, capital, labour, technology and energy are the basic inputs of production in developed and developing countries (Shafiei, 2013). Therefore, cobb-Douglas function can be written as:

$$
Y_{t}=A K_{t}^{\propto} L_{t}^{\beta} E_{t}^{\gamma}
$$

Where $\mathrm{E}_{\mathrm{t}}$ represents the energy consumption and $\gamma$ represent the elasticity of output to energy consumption. E represents the oil, fuel, electricity in this study to estimate the connection among different types of energy consumption with GDP.

$$
Y_{t}=A K_{t}^{\alpha} L_{t}^{\beta} O i l_{t}^{p_{1}} \operatorname{gas}_{t}^{p_{2}} \operatorname{Elec}_{t}^{p_{3}}
$$

Hence, the logarithmic form of Cobb-Douglas production function implies the log-linear function: 
$\ln Y_{t}=\ln K_{t}+\propto \ln K_{t}+\beta \ln L_{t}+p_{1} \ln$ Oil $_{t}+p_{2} \ln g_{a s_{t}}+p_{3} \ln$ Elec $_{t}+u_{t}$ (04)

Where $\mathrm{p}_{1}, \mathrm{p}_{2}$ and $\mathrm{p}_{3}$ represent the elasticities of oil, fuel and electricity respectively.

\subsection{Augmented Dickey-Fuller Test}

The ADF test evaluate whether the variables have unit root or not. ADF has analyzed with or without intercept to define the non-stationary of the variables. ADF test is shown as:

$$
\Delta \ln \mathrm{Y}_{\mathrm{t}}=\mu+\rho^{*} \ln \mathrm{Y}_{\mathrm{t}-1}+\sum_{\mathrm{i}=1}^{\mathrm{p}-1} \beta_{\mathrm{i}} \Delta \ln \mathrm{Y}_{\mathrm{t}-\mathrm{i}}+\mathrm{u}_{\mathrm{t}}
$$

\subsection{Co-integration Test}

Johansen experiment has trace test and max Eigen-value test.

\subsection{Granger Causality Tests}

The Granger causality test is used to invest causal connection among two variables. If the probability values of

Table 1: Stationary Test Result: Using ADF Test and PP

\begin{tabular}{|c|c|c|c|c|}
\hline Variables (Log) & \multicolumn{2}{|c|}{ ADF Test (P. Value, Intercept only) } & \multicolumn{2}{c|}{ PP Test (P. Value, Intercept only) } \\
\hline & Levels & First Difference & Levels & First Difference \\
\hline LGDP & 0.9673 & $0.0000^{*}$ & 0.9647 & $0.0000^{*}$ \\
\hline LLAB & 0.2895 & $0.0006^{*}$ & 0.2970 & $0.0005^{*}$ \\
\hline LELEC & 0.8897 & $0.0000^{*}$ & 0.7672 & $0.0001^{*}$ \\
\hline LGAS & 0.8389 & $0.0000^{*}$ & 0.9174 & $0.0000^{*}$ \\
\hline LINF & $0.0002^{*}$ & $0.0000^{*}$ & $0.0001 *$ & $0.0000^{*}$ \\
\hline LOIL & 0.5104 & $0.0006^{*}$ & 0.6106 & $0.0000^{*}$ \\
\hline LGFCF & 0.5176 & $0.0000^{*}$ & 0.3741 & $0.10 \%$ \\
\hline
\end{tabular}

Note: $*$ Sig. at $1 \%, * *$ Sig. at $5 \%, * * *$ Sig. $10 \%$
The above Table 1, results explain that GDP, labour, capital, Oil, gas and electricity are non-stationary in their level in both ADF and PP tests. However, they become stationary in the first difference at 1 percent significance level. At the same time, inflation is stationary at 1 percent in both their level of ADF and PP tests and first difference. Therefore, this study assumes that inflation is non-stationary in their level and they become stationary in the first difference. Hence, this rejects the null hypothesis and conclude that the series is stationary. Therefore, this study suggests the co-integration. the variable $X$ significantly influence to predict the value of another variable $\mathrm{Y}$, then $\mathrm{X}$ has a relationship with $\mathrm{Y}$ and vice versa. Following equation explain the experiment.

$$
\Delta \mathrm{Y}_{\mathrm{t}}=\sum_{\mathrm{i}=1}^{\mathrm{p}} \alpha_{\mathrm{i}} \Delta \mathrm{Y}_{\mathrm{t}-\mathrm{i}}+\sum_{\mathrm{j}=1}^{\mathrm{p}} \beta_{\mathrm{j}} \Delta \mathrm{X}+\mathrm{U}_{1 \mathrm{t}}
$$

$$
\Delta X=\sum_{i=1}^{p} \gamma_{i} X_{t-i}+\sum_{j=1}^{p} \delta_{j} \Delta Y_{t-j}+U_{2 t}
$$

\section{RESULT AND DISCUSSION}

\subsection{The Unit root test}

It check the stationary level of data series. Table 1 implies the finding of ADF and PP stationary experiment of the variables.

$\mathrm{HO}=$ non - stationary

$\mathrm{H} 1=$ stationary.

\subsection{Co-integration Test}

Johansen co-integration technique has used for the test the long-run relationships between GDP, labour, capital, oil, fuel, energy and inflation in Sri Lanka.

$\mathrm{H}_{0}: \operatorname{Rank}=0$

$\mathrm{H}_{1}:$ Rank $=1$

If $\mathrm{H}_{0}$ rejected, it indicates the long-run connection between the variables. The findings of co-integration experiment are presented as follow in table 2 and 3. 
Table 2: Result of Trace Cointegration Rank Experiment

\begin{tabular}{|c|c|c|c|c|}
\hline $\begin{array}{c}\text { Hypothesized } \\
\text { No. of CE }\end{array}$ & Eigenvalue & $\begin{array}{c}\text { Trace } \\
\text { Statistic }\end{array}$ & $\begin{array}{c}\text { Critical Value } \\
(0.05)\end{array}$ & Probability \\
\hline None $^{*}$ & 0.932183 & 171.2617 & 125.62 & 0.0000 \\
\hline At most 1 & 0.699009 & 95.91519 & 95.754 & 0.0487 \\
\hline At most 2 & 0.666203 & 62.29631 & 69.819 & 0.1717 \\
\hline At most 3 & 0.434088 & 31.57407 & 47.856 & 0.6355 \\
\hline At most 4 & 0.384690 & 15.63319 & 29.797 & 0.7378 \\
\hline At most 5 & 0.064494 & 2.035575 & 15.495 & 0.9945 \\
\hline At most 6 & 0.006013 & 0.168869 & 3.8415 & 0.6811 \\
\hline
\end{tabular}

*-rejection hypothesis at 0.05 level

Table 3: Result of Maximum Eigenvalue

\begin{tabular}{|c|c|c|c|c|}
\hline $\begin{array}{c}\text { Hypothesized } \\
\text { No. of CE(s) }\end{array}$ & Eigenvalue & $\begin{array}{c}\text { Max-Eigen } \\
\text { Statistic }\end{array}$ & $\begin{array}{c}0.05 \\
\text { Critical Value }\end{array}$ & Prob. \\
\hline None * & 0.9321830 & 75.34655 & 46.231 & 0.0000 \\
\hline At most 1 & 0.699009 & 33.61888 & 40.078 & 0.2226 \\
\hline At most 2 & 0.666203 & 30.72225 & 33.877 & 0.1137 \\
\hline At most 3 & 0.434088 & 15.94087 & 27.585 & 0.6708 \\
\hline At most 4 & 0.384690 & 13.59762 & 21.132 & 0.3989 \\
\hline At most 5 & 0.064494 & 1.866706 & 14.265 & 0.9934 \\
\hline At most 6 & 0.006013 & 0.168869 & 3.8415 & 0.6811 \\
\hline
\end{tabular}

*- rejection hypothesis at 0.05

The outcomes of the trace test imply that there are two cointegrating exits at the 1 percent significance level and but, the maximum-eigen test shows that one co-integrating equation exists at 1 percent significance level. Hence, this study has used the maximum-eigen test. The finding shows that Max-eigen value is 75.35 , Critical value is 46.23 , and Probability (Prob.) is 0.0000 . Here, Max-eigen value is higher than the critical value, and it is significant. Therefore,
Max-eigen test indicates that GDP, labour, capital, oil, gas, energy and inflation are cointegrated.

\subsection{The Long-run association of estimated variables}

The estimated model, can be written as follow in the longrun:

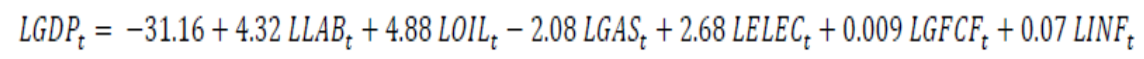

The model explains that gas consumption has a statistically significant negative relationship to the GDP in Sri Lanka whereas labour force, capital formation, inflation, oil and electricity consumption have a positive and statistically significant relationship with GDP.

Labour force indicates a positive and statistically significant relationship with GDP. So, while the labour force rises, production will increase and that leads to increase in gross domestic product and vice versa. It implies that other factors are remaining constant, while labour force of Sri Lanka increases by 1 percent, GDP will increase by 4.32 percent in long run. Further, oil and electricity consumption shows a positive and statistically significant relation on GDP. Therefore, while other factors are remaining constant, when oil and electricity consumption increases by 1 percent, GDP will rise by the 4.88 percent and 2.68 percent respectively. Similar results were found by Chaudhry et al. (2012).

Finding explains a negative association among gas consumption and GDP in Sri Lanka. This implies that 1 percent increase in gas consumption leads to approximately 2.08 percent decrease in GDP in Sri Lanka. Because gas consumption is used more by the household than the commercial and manufacturing industries.

Gross capital formation shows a positive and statistically significant relation with GDP. It implies that, when the capital formation increases, that leads to rise in investment opportunities and stimulate the increase in GDP. Likewise, Inflation also shows the positive and statistically 
significant association with GDP. In supply side, when the inflation increase, it leads to higher production and induce the

GDP level.

Table 5. Result of Granger Causality Experiment

\begin{tabular}{|l|l|l|l|}
\hline Null Hypothesis & Lag & F-Statistic & Probability \\
\hline Electricity does not Granger Cause GDP & 2 & 0.06794 & 0.0362 \\
\hline GDP does not Granger Cause Electricity & 11.8619 & 0.0018 \\
\hline GAS does not Granger Cause GDP & 2 & 11.2255 & 0.0023 \\
\hline GDP does not Cause GAS & 3.20066 & 0.0841 \\
\hline OIL does not Granger Cause GDP & 0.10253 & 0.0411 \\
\hline GDP does not Cause OIL & 2 & 0.98936 & 0.0351 \\
\hline GAS does not Granger Cause Electricity & 4.03230 & 0.3418 \\
\hline Electricity does not Cause GAS & 1.15623 & 0.2911 \\
\hline OIL does not Granger Cause Electricity & 4.33649 & 0.0462 \\
\hline Electricity does not Cause OIL & 2 & 2.87565 & 0.1006 \\
\hline OIL does not Granger Cause GAS & 0.02788 & 0.8686 \\
\hline GAS does not Cause OIL & & \\
\hline
\end{tabular}

This study used oil, electricity and gas as proxies of energy consumption in this study. Table 5 explains the pairwise Causality among oil, gas, electricity and GDP in Sri Lanka. Findings suggest that there exists bi-directional causality in oil, gas and electricity consumption in Sri Lanka. The results reveal that electricity, gas and oil consumption causes GDP and GDP leads to electricity consumption and oil consumption. This suggests that an increase or decrease in economic growth in Sri Lanka will have a significant impact on electricity and oil consumption and vice versa. Further, gas consumption and oil consumption do not Granger causes electricity, but electricity Granger cause gas consumption and oil consumption. It implies that unidirectional causality. But, oil and gas have no causality in Sri Lanka.

\section{CONCLUSIONS}

Energy is necessary and desirable since energy consumption has an influential impact on sustainable growth of a country and quality of life. Therefore, this research purposes to investigate the association among energy consumption and GDP of Sri Lanka in the period of time 1980 to 2017. Specifically, study aims to empirically examine the causal association between energy consumption and GDP, to explore long-run relationship among energy consumption and gross domestic product and to examine the effect of all related independent variables on GDP and its future implications. To achieve the aims of the research, this research has used the secondary data and collected data are analyzed using EViews 10 statistical; software.

According to the findings of the study, it reveals that all variables seems non-stationary at the level, however, becomes stationary at first difference. Johansen-Cointegration outcomes clarify that there occurs a long-run association among variables in this study. According to the model gas consumption has statistically significant negative relationship to the GDP Sri Lanka whereas labour force, inflation, gross domestic formation, oil and electricity consumption have positive and statistically significant relationship with GDP.

Further, Granger causality findings suggest that there happens bi-directional causation in oil, gas and electricity consumption in Sri Lanka. The outcomes expose that electricity, gas and oil consumption do Granger causes GDP as well as GDP affect electricity, gas and oil consumption. Oil and Gas implies the unidirectional causality with electricity. But, oil and gas have no causality in Sri Lanka. Hence, this research concluded that consumption of energy has a connection and significantly impact the Sri Lanka's economic growth.

\section{Recommendations}

The findings conclude, gas consumption leads to Sri Lanka economic growth. Therefore, the reduction in gas consumptions will affect economic growth. Hence, Sri Lanka should utilize the gas consumptions in manufacturing and commercial industries. Further, these findings indicate that changes oil and electricity consumption will affect economic growth and vice versa. So, government should take actions to reduce the taxes and interest on oil and electricity consumption. Sri Lankan government want to invest in natural gas, and hydroelectricity. This will lead to reducing the import burden of energy on the current account. At the same time, consumers also should utilize energy resource. Government should implement solar energy system projects to generate the electricity to fulfil the needs of the people. Further, government want to bring price differences in consuming the energy, especially in electricity consumption.

\section{REFERENCES}

1. Alp, E. A. (2016). Energy Consumption and Economic Growth in OECD Countries. International Journal of Energy Economics and Policy, 6(4), 753-759.

2. Anthony N. Rezitis, \& Shaikh Mostak Ahammad. (2015). Relationship between Energy Consumption and Economic Growth in South and Southeast Asian Countries: A Panel Vector Autoregression Approach and Causality Analysis. International Journal of Energy Economics and Policy, 5(3), 704-715.

3. Buhari Dogan and Osman Deger. (2016). How Globalization and Economic Growth Affect Energy Consumption: Panel Data Analysis in the Smaple of Brazil, Russia, India, China Countries. International Journal of Energy Economics and Policy, 6(4), 806-813. Retrieved from http://www.ecojournals.com

4. Congress,U.S. (2019). Energy in Developing Countries, OTA-E-486 Washington: DC:U.S. Government Printing Office. 
5. Faisal Faisal, Turgut Tursoys \& Ozlem Ercantanb. (2017). The relationship between energy consumption and economic. 9th International Conference on Theory and Application of Soft Computing. 120, pp. 671-675. Hungary: Procedia Computer Science. Retrieved from www.sciencedirect.com

6. Gillaspy, R. (2013). Energy consumption of the world:The Differences in Consumtion Between Developing and Developed Nations. Retrieved from Study.com: https.//study.com

7. Gulzara Tariq, Huaping Sun, Muhammad Haris, Hafiz Mustansar Javaid \& Yushen Kong. (2018). Energy Consumption and Economic Growth: Evidence from Four Developing Countries. American Journal Of Multidisciplinary Research, 7(1), 100-107.

8. Hou, Q. (2009). The Relationship between Energy Consumption Growths and Economic. International Journal of Economics and Finance, Vol. 1( No. 2), 232-237. Retrieved from www.ccsenet.org/journal.html

9. Imran Sharif Chaudhry, Noreen Safdar \& Fatima Farooq. (2012). Energy Consumption and Economic Growth: Empirical Evidence from Pakistan. Pakistan Journal of Social Sciences, 32(2), 371-382.

10. Jungcurt, S. (2019). Global Energy Demand in 2018 Grew at Fastest Pace in a Decade. Retrieved from SDG Knowledge Hub : https://sdg.iisd.org

11. Michael T. Toman \& Barbora Jemelkova. (2003). Energy and Economie Development: An Assessment of the State of Knowledge. Energy Jornal, 24, 1-21. Retrieved from https://www.semanticscholar.org

12. Ministry of Power and energy. (2015). Sri Lanka Energy sector Development Plan for a Knowledge-based Economy. Sri Lanka. Retrieved from http://powermin.gov.lk

13. Mohd Shahidan Shaari, Nor Ermawati Hussain \& Mohammad Shariff Ismail. (2012). Relationship between Energy Consumption and Economic Growth: Empirical Evidence for Malaysia. Business Systems Review, 2(1), 17-28.

14. Overland, I. (2016). Energy: The missing link in globalization. Energy Research and Social Science, 122-130.

15. Shafiei, S. (2013). Economic Growth, Energy Consumption, and Environment: Assessing Evidence from OECD Countries. Curtin University of Technology.

16. Syed Muhammad Atifa \& Muhammad Wasif Siddiqib. (2012). The Electricity Consumption and Economic Growth Nexus in Pakistan: A
New
Evidence.
MPRA.
Retrieved
from

https://mpra.ub.uni-muenchen.de/id/eprint/41377 